\title{
Would harmonizing public land forest policies, Criteria and Indicators, and certification improve progress towards Sustain- able Forest Management?: A case study in Alberta, Canada
}

\author{
by P.J. Golec ${ }^{1}$ and M.K. Luckert 1,2
}

\begin{abstract}
As the concept of Sustainable Forest Management (SFM) has evolved, governments and other stakeholders have pursued three important frameworks for defining and pursuing SFM: public land forest policies, Criteria and Indicators and certification. In Canada, these three approaches frequently operate simultaneously as policy frameworks for private firms managing forests on public lands. Harmonization of these three frameworks could create potential benefits by simplifying a complicated array of sometimes conflicting forest management standards. But there are also potential costs of harmonization that could arise out of the diverse conditions that embody SFM. The diversity of social values and ecological conditions associated with forests creates difficulties in designing processes that are representative of stakeholders' interests. Moreover, this variety poses challenges to designing standards that are sufficiently flexible to address local conditions, yet useful in contributing to SFM planning and reporting at regional, provincial and national scales. Within this context, we suggest that the diversity inherent in SFM will continue to be accommodated by multiple management frameworks, unless a single framework arises that shows itself capable of being trusted by stakeholders and of being sufficiently flexible to accommodate various definitions of Sustainable Forest Management.
\end{abstract}

Key words: Sustainable Forest Management, forest certification, Criteria and Indicators, public forest policy, harmonization of Sustainable Forest Management frameworks, case study, Canada, Alberta

\section{RÉSUMÉ}

Au fur à mesure de lévolution du concept d’aménagement forestier durable (AFD), les gouvernements et les autres intervenants ont élaboré trois importants cadres de travail pour définir et approfondir l'AFD : les politiques forestières du territoire forestier public, les Critères et Indicateurs et la certification. Au Canada, ces trois approches se traduisent fréquemment en cadre de référence politique pour les entreprises privées qui aménagent les forêts du domaine public. L'harmonisation de ces trois cadres de travail pourrait engendrer possiblement des avantages en simplifiant un ensemble complexe de normes d’aménagement forestier parfois en contradiction entre elles. Mais il existe également certains coûts d'harmonisation qui pourraient surgir sous certaines conditions entourant l'AFD. La diversité des valeurs sociales et des conditions écologiques associées aux forêts engendre des difficultés lors de la conception des processus qui sont représentatifs des intérêts des intervenants. De plus, cette variété constitue un défi pour établir des normes qui soient suffisamment flexibles pour répondre aux conditions locales, tout en étant utiles en terme de contribution à la planification de l'AFD et de description des résultats à léchelle régionale, provinciale et nationale. Relativement à ce contexte, nous suggérons que la diversité inhérente de l'AFD continuera dêtre reprise par plusieurs cadres de travail, à moins qu'un seul cadre de travail ne soit par lui-même capable dêtre jugé fiable par les intervenants et dêtre suffisamment flexible pour répondre aux différentes définitions de laménagement forestier durable.

Mots clés : aménagement forestier durable, certification forestière, Critères et Indicateurs, politiques forestières publiques, harmonisation du cadre de travail de l’aménagement forestier, étude de cas, Canada, Alberta

\footnotetext{
${ }^{1}$ The authors are Graduate Student, Department of Renewable Resources, 751 General Services Building and Professor, Department of Rural Economy, 515 General Services Building, University of Alberta, Edmonton, Alberta T6G 2H1.

${ }^{2}$ Corresponding author. E-mail: marty.luckert@ualberta.ca
} 


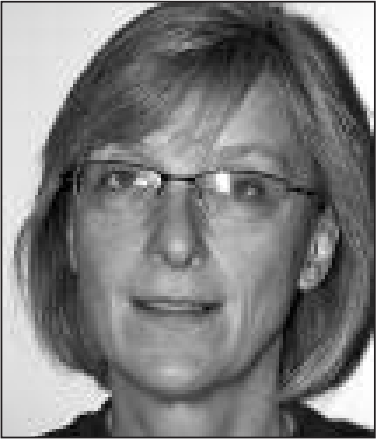

P.J. Golec

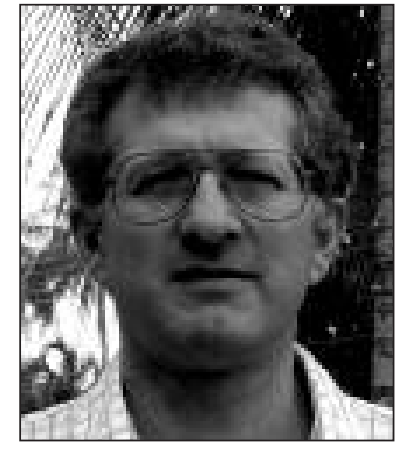

M.K. Luckert

\section{Introduction}

Sustainable Forest Management (SFM) is an evolving concept that must balance the social, economic and environmental values of those with legitimate interests in forests (Raison $e t$ al.2001). As the concept of SFM has progressed, governments and other stakeholders have been working to develop policy frameworks for defining SFM and for measuring and guiding forest management activities toward it. Although many systems for defining and pursuing SFM have arisen, ${ }^{3}$ three frameworks currently prevalent are public land forest policies, Criteria and Indicators (C\&I) and certification.

Prior to the emergence of the notion of SFM, governments worldwide had various policies designed to regulate the activities of private firms operating on public forest lands. In this paper, we refer to these variants as public land forest policies. However, as the concept of SFM developed, two new frameworks have arisen out of distinct but parallel processes. C\&I were developed, with consultative processes frequently led at the national level of governments, for guiding public land management towards SFM. Certification, on the other hand, was mainly developed by environmental non-governmental organizations (ENGOs) to be used by private companies for communicating information about forest practices to consumers of forest products.

As the pursuit of SFM continues, public land forest policies are evolving in the presence of C\&I and certification processes. In such cases, private firms operating on public lands may face all three of these types of frameworks simultaneously. With so many management frameworks coming together, issues of harmonization among these different SFM frameworks have arisen. A lack of harmonization can give firms conflicting incentives (e.g., Haener and Luckert 1998), and create overlaps in planning (Niemann and Innes 2004). Therefore, to the extent that frameworks could be effectively harmonized, we would have processes that better meet the objectives of SFM with reductions in planning costs. But harmonization may also involve costs. Too much harmonization could lead to forest management that fails to accommodate

\footnotetext{
${ }^{3}$ There are numerous other types of frameworks for pursuing SFM on public and private lands that vary between jurisdictions. For example, in the United States, there are state forest practice acts that regulate forestry on private lands. (e.g., Boyd and Hyde 1989). In Canada, there are also a number other initiatives that influence forest management on private and public lands (e.g., Niemann and Innes 2004).
}

the non-harmonized values of varied stakeholders, and could also lead to an inability of frameworks to accommodate local variability in ecosystems and values.

In this paper, we investigate the interrelationships among these different frameworks and discuss costs and benefits associated with attempting to harmonize them in order to provide a more coherent policy framework for pursuing SFM. Investigating the issues associated with harmonization provides insights into situations that may condition the evolution of forest policies.

We start with a brief history of the emergence of certification systems and C\&I, and describe how these worldwide trends have played out in Canada. This history discloses that there are differing views of SFM behind the alternative management frameworks that have evolved. We then trace these trends down to the forest planning level, with a focus on a case study of Alberta. This study shows how policies have evolved in a province that is attempting to use certification and C\&I as a basis for its public land forest policy to regulate private firms operating on public lands. We then discuss benefits and costs of harmonizing public land forest policies with certification and C\&I, including potential implications for regulators, ENGOs and private firms. The conclusions identify lessons to be learned from Canadian experiences with implications for whether and how SFM frameworks may, or may not, become harmonized.

\section{A Brief History of Certification and C\&I Development in Canada}

When intergovernmental processes did not achieve a global forest convention at Rio de Janeiro in 1992, ENGOs intensified their focus on certification as a way of measuring SFM (Cashore et al. 2003). These measurements involved the development of "standards", which frequently refer to a reference level that firms may wish to meet or exceed, in order to achieve certification. These standards can also provide a common basis for judging the performance of forest management.

A number of certification systems with differing standards have been developed. We limit our description to the emergence of the Forest Stewardship Council (FSC), the International Organization for Standardization (ISO), ${ }^{4}$ and the Canadian Standards Association (CSA), as these are the primary systems operating in Canada. We begin by describing the emergence of FSC and ISO, and then describe how C\&I were being developed concurrently. We then describe how CSA certification emerged as an early attempt at harmonization.

The FSC was founded in 1993 "to support environmentally appropriate, socially beneficial and economically viable management of the world's forests" (FSC 2004b). FSC required the establishment of national working groups that did not include governments, and that limited business influence to develop local indicators, thereby institutionalizing processes that differ dramatically from traditional public policy processes (Cashore et al. 2003). The council developed a

\footnotetext{
${ }^{4}$ Despite the fact that the acronym ISO does not match the ordering of the letters in International Organization for Standardization, it is commonly used as an acronym for the organization. The acronym originated from the Greek word "ISO" meaning "equal" and was chosen by the International Organization for Standardization as a name for their standards.
} 
framework of 10 Principles of Forest Stewardship and 56 criteria that apply to all tropical, temperate and boreal forests (FSC 2004a). Implementation of the FSC framework is overseen by a national working group in each country. In Canada, regional standards are developed by coordinating committees for each Ecoregion. Membership is a representation of three different groups, called chambers, representing environmental, social and economic interests. Canada has a fourth chamber for Aboriginal participants. Decisions require a $75 \%$ approval vote from each chamber to establish or change a performance threshold, thereby ensuring that no one sector dominates decision making (Tan 2003).

In 1946, the ISO formed to promote trade in numerous sectors of the economy by developing voluntary standards. In 1996, the ISO 14000 series was adopted as an international environmental management framework and two years later, a technical report was released to assist forestry organizations using the framework (ISO 1998). ISO requires compliance with applicable laws and a management system that defines standards. However, it is the company's management system being audited and certified, not the outcomes in the forest. All ISO standards are voluntary, market-driven and developed to satisfy industries and customers worldwide, taking into account a wide range of interests (ISO 2003). Standards are reviewed at approximately five-year intervals.

While certification systems were developing, governments meanwhile followed up from Rio de Janeiro with their own means of measuring progress towards SFM using C\&I. A seminar sponsored by the Conference on Security and Cooperation in Europe held in Montreal in June, 1993, was the start of what is now known as the Montréal Process; a commitment by twelve countries, including Canada, to develop C\&I for non-tropical forests (Montréal Process Criteria \& Indicators 1999). This agreement resulted in the Santiago Declaration, issued in 1995, containing seven criteria and 67 indicators for sustainable forest management of temperate and boreal forests. These C\&I recognise the importance of forests to the well-being of local populations, national economies and to the global biosphere (McDonald and Lane 2004). Each participating country has the responsibility to build its own national framework based on these C\&I. In Canada, the Canadian Council of Forest Ministers (CCFM) started work in 1993 defining, measuring and reporting on Canadian C\&I and (two years later) published Defining Sustainable Forest Management: A Canadian Approach to Criteria and Indicators (CCFM 1996). A revised version was published in 2003 (CCFM 2003).

The concurrent development of C\&I and certification schemes created different ideas about how to achieve SFM. The subsequent development of the CSA framework was an effort to address the divergence of the Canadian C\&I and certification streams with a unified certification approach. The CSA solicited input from a broad range of stakeholders, including governments and environmental groups, to build a framework based on the international ISO14000 series framework that also incorporated the CCFM C\&I. In 1996, the CSA released CAN/CSA-Z809-96 A Sustainable Forest Management System: Specifications Document, which specifies what must be done by a forest manager or owner to register a Sustainable Forest Management system (CSA 1996). While CSA has used the CCFM criteria, it does not use their indicators, relying instead on an extensive public consultation process to develop local values, objectives, indicators and targets. It is a management systems audit and, as such, has a large degree of flexibility in the design and measurement of progress. A company establishes a system of management and planning and sets its own standards in compliance with government regulations (Gale and Burda 1998). CSA certification shows that a company is following its own system and is operating legally.

Some of the participants in the CSA process (particularly some ENGOS) have not found the resulting framework satisfactory. As such, ENGOs tend to favour FSC as a framework while CSA is viewed more as an industry- and governmentdriven initiative. For example, a report by the Alberta Wilderness Association, Albertans for a Wild Chinchaga, Canadian Parks and Wilderness Society - Edmonton Chapter, and the Federation of Alberta Naturalists (2001) states: "Forest Stewardship Council (FSC) certification is currently the only demonstrably independent system that has broad international support from indigenous people and other forest users, industry, retailers and conservation groups."

Although the federal government took the lead in negotiating international agreements and developing national frameworks such as the CCFM C\&I, there was provincial government participation. ${ }^{5}$ However, there are no legislated requirements for implementing these C\&I at the provincial level. Nonetheless, some provinces are using at least part of this framework. The next section will describe how Alberta has chosen to implement these C\&I by using part of the CSA framework as the basis for its provincial forest management policy.

The main interrelationships among stakeholder organizations and SFM frameworks are summarized in Fig. 1. Public land forest policies are shown to primarily be the domain of provincial governments, with industry contributing secondarily to the process. The federal government is shown to be the primary driver for the C\&I, with provincial governments, industry and ENGOs playing a secondary role. ISO is shown to be an industry-led initiative as it has little, if any, government or ENGO input. FSC certification is shown to be primarily an ENGO-led initiative with industry playing a secondary role. CSA certification is shown to arise from Canadian C\&I and ISO certification, where organizational influences are largely from the federal government and industry. Finally, public land forest policies and all three certification schemes are shown to influence industry practices.

\section{An Alberta Case Study}

Prior to 1990, forest management plans for most of Alberta were prepared by government personnel with little formal public input, based on a common template. ${ }^{6}$ Provincial headquarters staff completed the analyses and calculated the har-

\footnotetext{
${ }^{5}$ Provincial governments were also participating in provincial, regional and local C\&I processes.

${ }^{6}$ By way of example, forest management plans prepared by Alberta Forestry, Lands and Wildlife in the late 1980s for Forest Management Units E1, E2, E5, R3 and R4 have exactly the same table of contents, and the lists of figures, tables and appendices are nearly identical (Alberta Forestry, Lands and Wildlife 1986, 1987, 1988, undated [a], undated $[\mathrm{b}])$.
} 


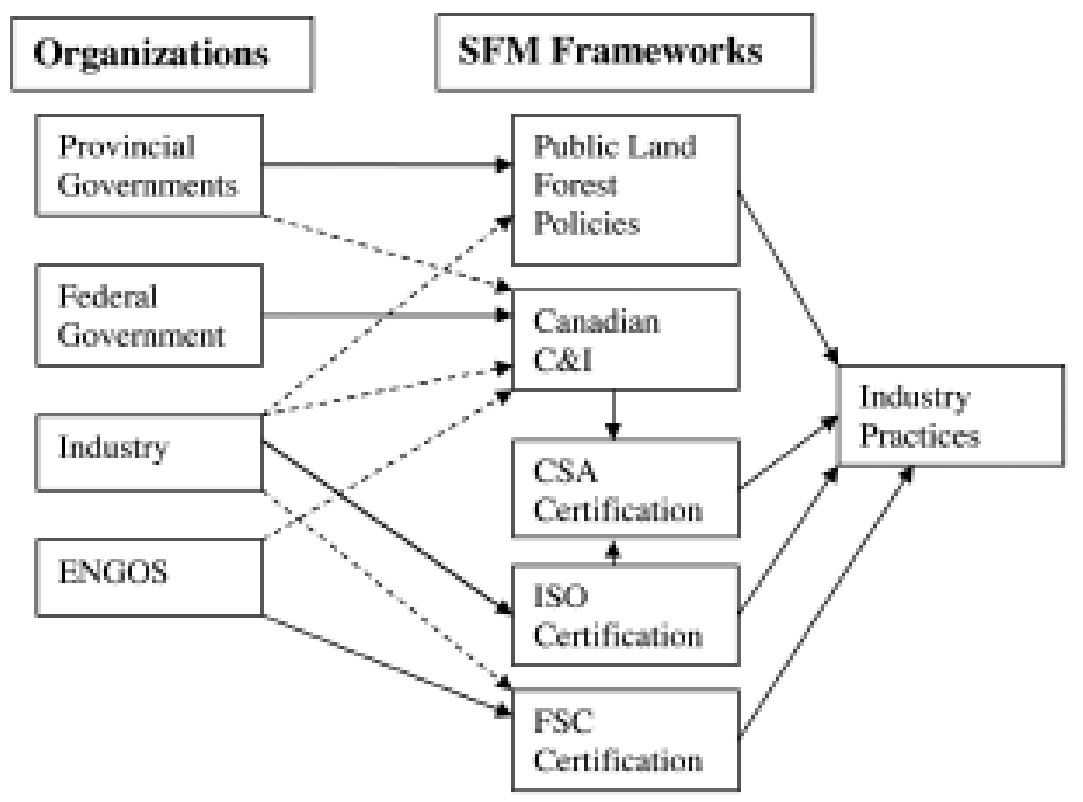

Primary Drivers $\longrightarrow$ Secondary Drivers ${ }^{\cdots \cdots \cdots}$

Fig. 1. Interrelationships between Organizations and SFM Frameworks

vest levels for each Forest Management Unit. Responsibility for detailed forest management plans now rests with corporations for over two thirds of the forested land in Alberta. Government staff members participate on planning teams, review and approve submissions, and mediate disputes between competing interests.

In order to guide the preparation of detailed forest management plans, Alberta Sustainable Resource Development (ASRD) and its predecessors ${ }^{7}$ have published various policy documents. Historically, management practices were highly prescriptive, allowing forest companies little latitude in their management practices. However, this approach changed significantly in 1998 with the Interim Forest Management Planning Manual: Guidelines to Plan Development (Alberta Environmental Protection 1998). In preparing detailed forest management plans, companies were expected to develop their own resource management philosophy and goals, and to rationalize the goals in terms of risks and opportunities. This change reflected an "objectives-based" approach that attempted to avoid specificity in order to accommodate the heterogeneity in ecosystems, public values and in companies that exist across the province. Companies were expected to negotiate their own ground rules, either within 6 months of

\footnotetext{
${ }^{7}$ Since 1980, the name of the provincial department responsible for forestry has been Alberta Energy and Natural Resources; Alberta Forestry, Lands and Wildlife; Alberta Environmental Protection; Alberta Environment and Alberta Sustainable Resource Development. Citations reflect the name of the agency at various points in time.
}

signing their Forest Management Agreement, or within six months of detailed forest management plan approval (ASRD 2004b). The government suggested subject areas for defining management objectives for company operations that included biodiversity, forest connectivity, ecological integrity, timber sustainability, fibre priorities, forest health, tree quality and genetics, aesthetic values, access and others. Implementation was to be through operating plans, but the manual states, "The content of these operating plans is not prescribed in order to provide each organization with the flexibility to define is own operating plan framework" (Alberta Environmental Protection 1998). This flexibility allowed for innovation on the part of companies in addressing local concerns. Companies were not required to link their plans with the C\&I that had recently been developed by the CCFM.

The objective-based approach resulted in a wide variety of goals, objectives, strategies and performance monitoring initiatives being adopted by companies across the province. This diversity caused problems for government personnel. Although all levels of the responsible provincial ministry were involved in review and approval of the plans, the regional offices played key roles (Alberta Environmental Protection 1998). With so much diversity in forest management approaches, negotiations between individual companies and local government representatives were, at times, extended due to differences in interpretation of the plan requirements. These negotiations resulted in a protracted plan review process. All companies have a specified period (most commonly either three or five years from the effective date of their Forest Management Agreement) to prepare a detailed forest management plan (ASRD 2004b). Comparing dates of when detailed forest management plans were actually approved (Forest Watch Alberta 2001) with due dates listed in the Forest Management Agreements reveals that none of the five that were due in January, 2001 were approved on time.

Another problem that the government faced from the diversity in company plans was in the area of data collection and reporting. As a member of the CCFM and signatory to the1998 National Forest Accord, the provincial minister responsible for forests had obligations to report on provincial activity towards national C\&I. A progress report on Alberta's Implementation Action Plan for the National Forest Strategy (1998-2003) re-affirmed the province's commitment to "....report fully and regularly on criteria and indicators of sustainable forest management as outlined in CCFM and Montréal Process frameworks", and ensure "...that forest management plans include monitoring and reporting on measurable objectives and indicators, consistent with CCFM criteria and 
indicators framework" (Government of Alberta 2000). ${ }^{8}$ However, because of the diversity of approaches taken by companies, the province was lacking a framework to easily consolidate information provided by companies for that purpose.

Within five years of releasing the 1998 manual (Alberta Environmental Protection 1998), the Alberta government saw a need to institute some consistency over forest management planning provincially and a decision was made to use an adapted CSA framework. The CSA framework incorporates the CCFM criteria, enabling Alberta to more easily meet its national reporting commitments, while providing a more rigid structure for detailed forest management plan development. The Alberta Forest Management Planning Standard Draft (2) (ASRD 2004a) was publicly released in November 2004. An updated version, with ground rules contained in a separate document, was released for public review in June 2005 (ASRD 2005) and Version 4.1 (ASRD 2006a) was formally approved in the spring of 2006.

The Alberta standard states that a forest management plan ..."must meet the requirements of applicable CSA Z809-02 clauses as described in the manual", but neither forest certification nor third party audits are mandatory (ASRD 2004a, 2005, 2006a). Responsibility for coordination of the plan review and approval has been returned to the central provincial office while regional staff provide assistance and local input. Ground rules are to be consistent throughout the province with some minor allowances for local conditions or history (ASRD 2004a, 2006b). The more centralized approach is evident in the prescriptive requirements for detailed forest management plans that are contained in the new planning framework. A comparison of requirements for detailed forest management plans in 1998 and 2006 is shown in Table 1.

This change in focus on the part of ASRD appears to be an attempt to harmonize forest policy with the CSA certification system, but it is only a partial harmonization. The CSA framework been interpreted in a way that allows some sections to be implemented and others to be ignored. Four key differences are evident.

First, the Alberta framework does not require a SFM policy statement. Following the ISO 14000 framework, CSA developed standards for a management system. The five basic elements of a management system are commitment and policy, planning and prioritization, implementation, measurement and evaluation, and review and improvement (ISO 2003). A core requirement of a management system for sustainable forests, as defined by the CSA framework, is an indication of the organization's commitment to SFM in a policy statement. The Alberta framework makes an SFM policy statement optional.

Second, the Alberta framework is more prescriptive than the CSA framework. The CSA structure has been criticized for being too flexible with some elements and not detailed enough to be interpretable in the field (von Mirbach [undated]). CSA certification uses the CCFM criteria, with CSA-defined elements and leaves the development of indica-

\footnotetext{
${ }^{8}$ Although Alberta did not sign the 2003 Canada Forest Accord, provincial representatives continue to participate and support the Canadian Council of Forest Ministers and its associated committees, including the C\&I Task Force and two of the Technical Working Groups.
}

tors to the organization seeking certification. ${ }^{9}$ The Alberta framework is more prescriptive by specifying a core group of indicators and performance standards. These performance standards, in turn, reference compliance with existing regulations and policies and include CCFM indicators as well as other requirements. An example of how the Alberta policy has specified indicators corresponding with CCFM values is shown in Table 2. Each of the indicators has a target value that is to be specified during the planning process (usually at the management subunit level). Despite the specific nature of these indicators, the Alberta framework states "The Organization shall adopt a list of values objectives, indicators and targets shown in Annex 4, which are the minimum VOITs required" (ASRD 2006a).

Third, the Alberta framework differs from the CSA framework with respect to flexibility regarding public consultation. Clause 6 of the CSA Z809-02 Requirements and Guidance document states:

"The organization, in conformance with the public participation process requirements set out in Clause 5, shall identify DFA-specific [defined forest area-specific] values, objectives, indicators, and targets for each of the CSA SFM elements described in Clause 6, as well as any other values associated with the DFA [defined forest area]" (CSA 2002).

However, with the Alberta framework, some aspects of public consultation, as required by the CSA framework, become unnecessary as they are prescribed with a set of 17 values, 22 objectives, 28 indicators and 31 targets. The Alberta framework states:

"The mandatory values, objectives, indicators and targets (VOITs), identified by Alberta in Annex 4 shall be addressed in FMPs [forest management plans]" (ASRD 2006a).

The prescription of values, objectives, indicators and targets clearly limits the flexibility of plan development as intended by the CSA framework. Moreover, the Alberta government has not yet actively invited the public to participate in the definition of values, objectives, indicators and targets that will apply across the province, although the public has been given the opportunity to comment on the government developed standards. However, companies are expected to include a wide range of public participants throughout the preparation period of their detailed forest management plans. Membership on companies' public participation groups is not prescribed by the CSA or Alberta frameworks, but direction is being given on group membership and operating rules. Moreover, regardless of the desires of the members of public participation groups, government representatives must be allowed to attend meetings.

Fourth, the Alberta framework expands the scope for public participation. It uses the detailed description of public participation requirements in the CSA framework as a basis for companies to develop 10-year Terms of Reference for their forest management planning. The Alberta framework requires Terms of Reference to be developed that describe

${ }^{9} \mathrm{CSA}$ certification is based on a hierarchical structure of respectively, criteria, elements and indicators. Criteria are more general concepts that become more directed and specific at the element and indicator levels. 
Table 1. Increased Specificity, between 1998 and 2006, in Detailed Forest Management Plan Requirements

Recent Requirements (2006) a

Corporate overview. Background of organization and all forestry operators with timber allocations.

Forest Management Approach. General approach and differences between operators.

Landscape Assessment. "Complete information presented in suitable text, tabular and map formats" including; administrative boundaries, physical condition, forest landscape pattern and structure, forest landscape disturbance and succession, wildfire threat assessment, fire regime analysis and landscape use.

Summary of any previous FMP and outcomes.

Statement of values, objectives, indicators and targets. A minimum of 17 values, 27objectives, 34 indicators and 37 targets prescribed with levels of many of the targets to be negotiated.

Current status and forecast for each indicator, including a description of the assumptions and analytical methods for forecasting.

A description of the chosen strategy including all significant actions to be undertaken and their associated implementation schedule.

A description of the monitoring program and the associated evaluation of actual and expected outcomes.

A demonstration of the linkages between short term and operational plans and the SFM Plan. The primary mechanisms for linkage are the spatial harvest sequence, silviculture prescription commitments and operating ground rules.

${ }^{\mathrm{a} A S R D}$ (2006a)

bAlberta Environmental Protection (1998)

"the process from the point of starting work on a detailed FMP [forest management plan] to starting work on the next FMP [forest management plan]" (ASRD 2006a). This greatly expands the scope of the CSA framework's basic operating rules for public participation in the preparation of a SFM plan.

In sum, the Alberta framework has fundamentally altered the CSA framework. The flexibility of the objective-based approach contained in the 1998 Interim Planning Manual has been abandoned in favour of adopting the CCFM criteria and parts of the CSA and ISO standards, while specifying provincial indicators. This increase in specificity will likely have a number of positive and negative consequences. On the positive side, increased specificity will promote consistency of data collection and reporting. Such consistency may expedite the approval of management plans and provide a "level playing field" for all companies. Moreover, outlining all management-related activities over the full 10-year life of a detailed forest management plan provides regulators with a detailed schedule of a company's commitments, simplifying their tracking and enforcement activities. And finally, expanding
No specified requirement

Interim Manual Requirements (1998) ${ }^{b}$

No specified requirement

Resource Management Philosophy

No specified requirement

Resource management goals (biological, economic and social).

No specified requirement

Forest management objectives, evaluation of resource management strategies and selection of the preferred forest management strategy.

Performance monitoring.

Performance monitoring.

the scope of prescribed public involvement in SFM planning may be welcomed by various stakeholders.

However, a number of potentially negative consequences may also occur. Failure to require a SFM policy statement may prevent companies from creating an overall vision to guide their SFM efforts. Second, the increased specificity of indicators will increase mandatory planning and data collection costs for companies, and could also increase monitoring costs for governments who check on company reporting. Third, the adoption of fixed values, objectives, indicators and targets could limit the potential influence of stakeholders. Finally, expanding the scope of public participation could be costly and unwarranted in areas where forestry issues are not a large public concern.

\section{Benefits and Costs of Harmonizing SFM Frameworks} The history of Certification and C\&I in the context of public land forest policies in Canada (with specific examples in Alberta) illustrate a number benefits and costs associated with attempts to harmonize SFM frameworks. 


\section{Canadian Council of Forest Ministers Values ${ }^{\mathrm{a}}$}

Maintain biodiversity at the landscape scale

Maintain biodiversity at the local/stand scale

\begin{tabular}{|c|c|}
\hline \multicolumn{2}{|l|}{ Alberta Indicators $^{\mathrm{b}}$} \\
\hline $\begin{array}{l}\text { - area of old, mature and young forest by broad } \\
\text { species group }\end{array}$ & $\begin{array}{l}\text { - number of water crossings in compliance with } \\
\text { provincial regulations }\end{array}$ \\
\hline - area/volume of living and dead trees left standing & - open seasonal/temporary forestry road length \\
\hline in cutblocks after harvest, by tree size and species & - area or occurrence of each uncommon plant \\
\hline - range of forest patch sizes & community \\
\hline $\begin{array}{l}\text { - percentage of harvested area having pieces of wood } \\
\text { greater than } 7.5 \mathrm{~cm} \text { in diameter lying on the ground }\end{array}$ & $\begin{array}{l}\text { - area of burned forest that has not had burned } \\
\text { trees harvested }\end{array}$ \\
\hline before and after harvest & - area of forest where trees have been blown down \\
\hline $\begin{array}{l}\text { - area of old interior forest in patches larger than } \\
100 \text { hectares by broad species group }\end{array}$ & by wind and left on the ground \\
\hline $\begin{array}{l}\text { - sensitive sites such as mineral licks and major } \\
\text { game trails }\end{array}$ & \\
\hline - open all-weather forestry road density & \\
\hline
\end{tabular}

aThese values are under Canadian Council of Forest Ministers Criterion 1, Biological Diversity (CCFM 1996) and Canadian Standards Association SFM Element 1.1, Ecosystem Diversity (CSA 2002).

bASRD (2006a)

Perhaps the single greatest motivation for harmonizing frameworks is the desire for a simplified framework within which to pursue SFM goals. For example, the harmonization of SFM frameworks could simplify and improve monitoring of forest practices. Currently, in addition to ongoing monitoring and reporting to government, Canadian forest companies are subject to government audits and most also have one or more certification audits, usually at different points in time. Each audit has its own unique set of indicators and evidence requirements. A single, harmonized framework would allow companies to better focus their efforts. Moreover, government monitoring costs could be drastically reduced if they are able to "free ride" on private certification costs. Furthermore, the independence of third party auditors in certification schemes may create a level of separation between the company and the government, providing a buffer from industrial and political influences on monitoring and increasing the credibility of the evaluation. ${ }^{10}$ ENGOs, governments, and companies could all benefit from the arms-length nature of such an assessment.

A single SFM framework may be seen as a good example of transparency and accountability in decision-making (e.g., for CSA, Vogt et al. 2000, von Mirbach [undated]). In contrast to a simplified and harmonized system, the many different frameworks in the current forest management environment

\footnotetext{
${ }^{10}$ Although it is commonly accepted that third-party audits are independent, the underlying business relationship could creative adverse incentives. If a company is paying an auditor to tell it that it is doing a good job, then the company may expect the auditor to tell it that it is doing a good job. If the auditor does not, the company may choose to hire another auditor that will.
}

can create confusion and lack of accountability. If interested publics (including consumers of forest products) are confused about which framework is followed by whom and why, it is difficult to assess who to hold accountable. Moreover, the resulting diversity makes comparisons between jurisdictions difficult, if not impossible. This causes problems for regulators wanting to compare or aggregate performance measures for monitoring and reporting purposes.

But simplicity and clarity can come at a cost when used to assess complex ecosystems managed under varying economic conditions and social values. While using a single SFM framework may make the process more transparent and accountable to the public, it may cause problems if land managers are prevented from utilizing the most appropriate practices by overly rigid rules (Hoberg 2001). Certification processes have struggled with this issue and have generally responded by allowing companies to develop forest management plans that are responsive to local economic, social and environmental conditions. During these processes, certification standards rely heavily on stakeholders' opinions to define indicators and may, at least in part, ignore the need for scientifically developed indicators (Kneeshaw et al. 2000). However, such processes can sometimes fail to rationalize necessary tradeoffs. For example, the CSA approach addresses each value individually without a weighting mechanism to prioritize, so the six different criteria may end up conflicting with one another (Vogt et al. 2000).

The diversity of values among stakeholders creates further challenges for harmonizing SFM frameworks. In the case of Canada, simplification was attempted by creating a new harmonized certification scheme (i.e., CSA). However, such efforts were only partially successful. The rift between 
ENGOs (with their preferred FSC certification) and the CSA indicates that it is difficult to create a harmonized approach while accommodating all of the relevant interests. This rift has trickled down to the provincial level and created problems of harmonizing SFM frameworks. Despite the attempt in Alberta at harmonizing public forest land policies and C\&I with ISO and CSA certification, there is at least one major forest company that has pursued FSC certification.

The political landscape within which certification and C\&I has evolved has changed the historic roles of interested parties. As Elliott and Schlaepfer (2001) note, "the forest ministries' acceptance of CSA developing the forest management standard with NGO involvement implies a change in roles, with part of policy development being delegated to the private sector, and participation being broadened." There are concerns that an increase in the prominence of structures like certification in forestry could change existing power relationships and affect other domestic and international policymaking processes (Cashore 2002). Therefore, the basic governance structures of forestry are changing. Such changes may be necessary to effectively pursue SFM. But whether these changes have improved (or will improve) progress towards SFM remains unclear.

Perhaps the most negative aspect of harmonizing public land forest policies and C\&I with certification schemes would be a reduction of choice. For example, if certification were adopted as part of a public land policy, then certification would no longer be voluntary, and benefits associated with having choices would be lost. The loss of choice could result in costs (financial and social) to both companies and ENGOs.

For companies, forest certification currently shows a voluntary commitment to sustainability over and above what is legally required by government. Maser and Smith (2000) argue that "the voluntary nature of certification and its ability to educate are imperative ... to its immediate credibility." Guldin (2003) reports that one of the key messages emerging from a meeting of the IUFRO task force on the forest science-policy interface in 2002 was that market-based approaches work better than regulatory approaches in policy implementation. Some of the incentives for companies to certify include pre-empting mandatory regulation, increasing the efficiency and effectiveness of regulations and improved relations with stakeholders (Khanna 2001). However, by harmonizing forest policy with a single certification framework, governments remove the company's choice of whether or not to certify as well as their ability to select a certification framework tailored to their interests.

For ENGOs, integrating certification into public land policies could force them to participate within a certification framework that they have not historically supported. For example, some ENGOs would likely be hesitant to take part in planning processes within the CSA framework. If this framework were the only mechanism available for influencing forest policy, the influence of ENGOs could be diminished because they would be losing their ability to choose the framework most closely aligned with their values.

\section{Conclusions}

Canadian experiences with certification, C\&I, and public forest land policies, show why harmonizing the three approaches may be difficult. Differences between SFM frameworks imply that harmonization is more complex than aggregating the various SFM standards and removing duplication. Harmonization also involves identifying and attempting to reconcile the specific parts of these frameworks that are different.

The root causes of some of these differences are likely to make reconciliation difficult. The movement toward certification has been characterized as a response to the perceived lack of sustainable management of the world's forests (Vogt et al. 2000). That is, there is a demand for a type of forest management that is not being met through other SFM frameworks, including public land forest policy. In jurisdictions with large areas of public forests such as Canada, certification schemes such as FSC represent a clear "end-run" around public forest land policies and C\&I initiatives. That is, certification does not exist because it is duplicative of C\&I and/or public forest land policies. It exists because it differs. Similarly, C\&I do not exist because they duplicate provincial forest policies. They exist because they differ.

Canadian experiences with certification, C\&I, and public forest land policies, show that there are costs and benefits associated with harmonization that appear to be guiding current mixes of SFM frameworks. Many of these costs and benefits can be characterized according to one of two key dimensions: representation of stakeholders and specificity of standards. All of the current frameworks guiding SFM in Canada have failed on one or both of these counts.

Historically, representation of stakeholders in public forest land policy processes in Canada has been characterized by a dominance of industrial and government influences (Howlet and Rayner 1995). As ENGOs have played increasing roles in SFM, there have been difficulties in finding common ground. A case in point is the CSA framework, which attempted to harmonize C\&I and ISO, but has not been accepted by many ENGOs who generally favour FSC. Accordingly, none of the current frameworks has the support of all stakeholders.

Regarding the specificity of standards, public land forest policy in Canada has historically been dominated by formalized regulation with little room for flexibility. The case study in Alberta shows how one province tried to increase the flexibility of public land regulations. But this flexibility was achieved at the expense of increased difficulty in government monitoring and reporting. Therefore, despite Alberta's recent attempt to increase flexibility, policy makers seem headed back towards more specificity, structured with the context of the national C\&I.

As attempts at harmonization continue, there may be synergies that emerge between the challenges associated with representation and the specificity of standards. For effective representation to occur, stakeholders must believe that processes are established so that their interests can be accommodated. Representation will only be improved if processes deliver increased chances of finding common ground among stakeholders. Similarly, the probability of finding common ground may improve if standards are more flexible and therefore able to accommodate differing SFM conditions. Some ENGOs have favoured more structured standards, presumably because they do not trust local processes to represent their concerns. But if standards are built with processes that stakeholders agree to and trust, then participants may be more willing to rely on local specifications of SFM rather than on more standardized dictums of what precisely constitutes SFM. 
If SFM frameworks head towards a more representative and flexible approach, the tasks of centralized government monitoring and reporting will likely change. The diversity of outcomes will likely make it so that governments may no longer be in a position to be able to monitor and report according to any single concept of SFM. Although such an approach would not simplify national accounting of progress towards SFM, if a harmonized framework emerges that is sufficiently representative and flexible, it will be easier for governments to find and report "good news" stories regarding SFM to the public.

In sum, if a harmonized framework is to emerge, the challenges posed by representation and specificity must be overcome. The core problem of providing a framework for SFM comes down to the great variety in values, conditions and practices of forests and the people who use them. That is, SFM implies diversity. That diversity will either come from a variety of SFM frameworks, or from a single framework of sufficient flexibility to accommodate diversity. To the extent that an SFM framework is successful in establishing trusted, representative processes that define and deliver SFM according to varied stakeholders' values, there is a chance for a single SFM framework to emerge. But this framework would have to be sufficiently flexible to accommodate numerous concepts of SFM. As long as perceptions of SFM conditions are too varied to be accommodated by one framework, there will continue to be multiple frameworks and a lack of harmonization in the pursuit of SFM.

\section{Acknowledgements}

Thanks to Richard Schneider and Helene Walsh for their helpful comments, though the paper is not meant to reflect their views. Also thanks to three anonymous reviewers. Research support was provided by the Sustainable Forest Management Network.

\section{References}

Alberta Environmental Protection. 1998. Interim Forest Management Planning Manual: Guidelines to Plan Development. Version: April, 1998. Land and Forest Service, Alberta Environmental Protection, Edmonton, $\mathrm{AB}$.

Alberta Forestry, Lands and Wildlife. 1986. E1 Forest Management Unit Forest Management Plan. Timber Management Branch, Alberta Forestry, Lands and Wildlife. Approved 86/07/14.

. 1987. E2 Forest Management Unit Forest Management Plan. Approved Feb 25/87. Alberta Forestry, Lands and Wildlife. Alberta Forest Service.

. 1988. R3 Forest Management Unit Forest Management Plan. Timber Management Branch, Alberta Forestry, Lands and Wildlife. Approved 88/07/06.

Undated (a). E5 Forest Management Unit Forest Management Plan. Timber Management Branch, Alberta Forestry, Lands and Wildlife. No approval date.

Undated (b). R4 Forest Management Unit Forest Management Plan. Timber Management Branch, Alberta Forestry, Lands and Wildlife. No approval date.

Alberta Sustainable Resource Development (ASRD). 2004a. Alberta Forest Management Planning Standard -Draft (2). Forest Management Branch, Public Lands and Forests Division, Alberta Sustainable Resource Development, November 2004.

2004b. Companies Awarded Forest Management Agreement Areas [online]. Available at http://www3.gov.ab.ca/srd/forests/managing/fma/companysummary.html [Accessed 6 Nov. 2004].
2005. Alberta Forest Management Planning Standard. Forest Management Branch, Public Lands and Forests Division, Alberta Sustainable Resource Development, Version 3.

2006a. Alberta Forest Management Planning Standard. Forest Management Branch, Public Lands and Forests Division, Alberta Sustainable Resource Development, Version 4.1.

2006b. Alberta Timber Harvest Planning and Operating Ground Rules Framework for Renewal. Forest Management Branch, Public Lands and Forests Division, Alberta Sustainable Resource Development.

Alberta Wilderness Association, Albertans for a Wild Chinchaga, Canadian Parks and Wilderness Society-Edmonton Chapter, and the Federation of Alberta Naturalists. 2001. Structural Impediments to FSC Certification in Alberta: Overcoming Barriers to Well-Managed Forests [online]. Available at http://www.boreal cetre.ca/reports/imped/imped.html [Accessed May 2, 2006].

Boyd, R.G. and W.F. Hyde. 1989. Forest Sector Intervention: The Impacts of Regulation on Social Welfare. Iowa State University Press, Ames, IA. 295 p.

Canadian Council of Forest Ministers (CCFM). 1996. Criteria and Indicators of Sustainable Forest Management in Canada. Technical Report, 1997. Natural Resources Canada - Canadian Forest Service, Ottawa, ON.

2003. Defining Sustainable Forest Management in Canada: Criteria and Indicators 2003. Natural Resources Canada - Canadian Forest Service, Ottawa, ON.

Canadian Standards Association (CSA). 1996. CAN/CSA-Z80996 A Sustainable Forests Management System: Specifications Document. Environmental Technology. A National Standard of Canada. Canadian Standards Association, Etobicoke, ON.

2002. CSA Standard Z809-02 Sustainable Forest Management: Requirements and Guidance. Canadian Standards Association. Mississauga, ON.

Cashore, B. 2002. Legitimacy and the privatization of environmental governance: how non-state market-driven (NSMD) governance systems gain rule-making authority. Governance: An International Journal of Policy, Administration, and Institutions 15(4): 503-529.

Cashore, B., G. Auld and D. Newsom. 2003. The United States' race to certify sustainable forestry: non-state environmental governance and the competition for policy-making authority. Business and Politics 5(3): 219-259.

Elliott, C. and R. Schlaepfer. 2001. Understanding forest certification using the Advocacy Coalition Framework. Forest Policy and Economics 2: 257-266.

Forest Stewardship Council. 2004a. FSC Principles and Criteria for Forest Stewardship. FSC-STD-01-001. Available at http://www.fsc. org/keepout/content_areas/77/71/files/FSC_STD_01_001_FSC_ Principles_and_Criteria_for_Forest_Stewardship_2004_04.PDF [Accessed 4 October 2004].

2004b. National Boreal Standard. Accredited by FSC August 6, 2004. Forest Stewardship Council, Canada Working Group.

Forest Watch Alberta. 2001. Planning and practices survey of FMA holders in Alberta. Available at http://www.forestwatchalberta.ca/ survey.pdf [Accessed 4 November 2004].

Gale, F. and C. Burda. 1998. The pitfalls and potential of eco-certification as a market incentive for sustainable forest management. In C. Tollefson (ed.). The Wealth of Forests: Markets, Regulation, and Sustainable Forestry. UBC Press, Vancouver, BC.

Government of Alberta. 2000. Alberta's Implementation Action Plan for the National Forest Strategy (1998-2003). Progress Report April 2000 [online]. Available at http://www.srd.gov.ab.ca/forests/ $\mathrm{fmd} / \mathrm{nfs} /$ index.html [Accessed 30 October 2004].

Guldin, R.W. 2003. Forest science and forest policy in the Americas: building bridges to a sustainable future. Forest Policy and Economics 5: 329-337.

Haener, M.K. and M.K. Luckert. 1998. Forest Certification: economic issues and welfare implications. Canadian Public Policy Vol XXIV, Supplement 2: S83-S94. 
Hoberg, G. 2001. The British Columbia Forest Practices Code: Formalization and Its Effects. In M. Howlett (ed.). Canadian Forest Policy. University of Toronto Press. Toronto, Ontario.

Howlett, M. and J Rayner. 1995. Do ideas matter? Policy network configurations and resistance to policy change in the Canadian forest Sector. Canadian Public Administration 38(3): 382-410.

International Organization for Standardization (ISO). 1998. Information to assist forestry organizations in the use of Environmental Management System standards ISO 14001 and ISO 14004. Technical Report ISO/TR 14061. First Edition 1998-12-15. International Organization for Standardization. Geneva, Switzerland. .2003. How are ISO standards developed? [online]. Last modified 2003-09-30. Available at http://www.iso.org/iso/en/stdsdevelopment/whowhenhow/how.html [Accessed 30 October 2004].

Khanna, M. 2001. Non-mandatory approaches to environmental protection. Journal of Economic Surveys 15(3): 291-324.

Kneeshaw, D.D., A. Leduc, P. Drapeau, S. Gauthier, D. Paré, R. Carignan, R. Doucet, L. Bouthillier and C. Messier. 2000. Development of integrated ecological standards of sustainable forest management at an operational scale. The Forestry Chronicle 76(3): 481-493.

Maser, C. and W. Smith. 2000. Forest Certification in Sustainable Development: Healing the Landscape. Lewis Publishers, Boca Raton, FL.

McDonald, G.T. and M.B. Lane. 2004. Converging global indicators for sustainable forest management. Forest Policy and Economics 6: 63-70.
Montréal Process Criteria and Indicators. 1999. The Montréal Process [online]. Available at http://www.mpci.org/rep-pub/1999/ broch_e.html [Accessed 4 October 2004].

Niemann, T and J.L. Innes. 2004. Streamlining local-level information for sustainable forest management. In J.L. Innes, G.M. Hickey and $\mathrm{B}$. Wilson (eds.). International perspectives on streamlining local-level information for sustainable forest management. A selection of papers from a conference held in Vancouver, Canada, August 28 and 29, 2000. Natural Resources Canada - Canadian Forest Service, Pacific Forestry Centre, Victoria. Information Report BCX-400. 109 p.

Raison, J.R., D.W. Flinn and A.G. Brown. 2001. Criteria and Indicators for Sustainable Forest Management. CABI Publishing. New York, NY.

Tan, A.L. 2003. On the Ground. Forest Certification: Green Stamp of Approval or Rubber Stamp of Destruction? A report commissioned by ForestEthics, Greenpeace and Sierra Club of Canada, BC Chapter. Available at www.goodwoodwatch.org.

von Mirbach, $M$. undated. Footprints in the forest: Current practice and future challenges in forest certification. Prepared for FERN by the Sierra Club of Canada. Available at www.sierraclub.ca/national/ programs/biodiversity/forests/csa-forest-standards.pdf.

Vogt, K.A., B.C. Larson, J.C. Gordon, D.J. Vogt and A. Fanzeres. 2000. Forest Certification: Roots, Issues, Challenges and Benefits. CRC Press, Boca Raton, FL. 